\title{
飛驒における夏どりホウレンソウのべと病発生と 防除についての一考察
}

\author{
安田弘之* - 河野幹幸** 大 大栗田文治** - 新谷 勲** \\ （岐阜県農業試験場・**飛驒病害虫防除所）
}

岐阜県飛驒地域の標高500～900m地帯の夏どりホウ レンソウは国の産地指定を受け, 中京・関西市場で夏 季緑葉野菜として供給增加が期待されており栽培面積 も 200 ha になろうとしている.これら飛驒地域の夏 どりホウレンソウの栽培は「パイプハウス屋根型被覆 栽培（以下雨よけ栽培という）による夏どりホウレン ソウ年 4 連作法」として技術体系が確立されつつあり, 栽培農家の経営安定に結びつきつつある。

飛驒地域に怙けるホウレンソウ栽培は 5 月から 10 月 にかけての冷涼な気候を利用した栽培であり, 元来ホ ウレンソウの生育にはビニル被覆は必要としないもの であるが，1）立枯病防止，2）被覆栽培による適期 作業，3）生育調節をするための省力灌水などのため に通称雨よけ栽培が定着したものである。しかし昭和 52 年のジネブ阂の登録変更は, はからずもこの飛驒地 域の夏どりホウレンソウの栽培技術の再検討を要する 問題を提起することとなった。すなわち, この夏どり ホウレンソウは高冷地ほど栽培の全期間を通じべと病 が発生し致命的な損害を与えることがしばしばみられ る.このべと病に対しては従来ジネブ剂によって対処 してきたが, 前述の通り農薬の登録上の問題から, こ れらジネブ剤が使用できないためべと病の発生を抑え 切れない場面がでてきたわけである。これはジネブ剤 を使用するということで成り立っていた夏どりホウレ ンソウの栽培技術体系が農薬の使用規制の面から成り 立たなくなったとみるべき問題である。ところで現在 ホウレンソウに使用できる農薬は TPN 剤のみであり, ベと病の発病抑制に力不足を訴える農家が多いので, 飛驒地域の夏どりホウレンソウ栽培における灌水とべ と病発生, TPN 粉剂の適用効果について調査をした ので報告する.

\section{1. 調查圃場概要}
調査围場 高山市冬頭町
品種 若草
播 種 昭和 53 年 9 月 2 日（当ハウス 3 作目）
収穫始め 昭和53年10月 5 日
灌水月日 9 月 3 日，9月 8 日，9月 21 日， 9 月 30 日, 10月 4 日

薬剂散布日 9 月 12 日, 9 月 20 日, 液剤 $150 \ell / 10 \mathrm{a}$, 粉剂 $3 \mathrm{~kg} / 10 \mathrm{a}$

発病状況べと病は 9 月 25 日に初発生し, その後 夢延した。

肥培管理 慣行

\section{2. 調査結果}

(1) 灌水とべと病発生について

雨よけ栽培における水分補給は塩ビ管の頭上配管か らの散水によっているが，一作期間の灌水回数は 5 〜 10回に及んでいる．ホウレンソウのべと病発生にこの 灌水が影響していると考えられるので, 灌水によるホ

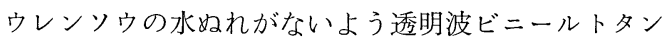
を栽培床上 $20 \mathrm{~cm}$ に打き, べと病の発生差をみたとこ ろ第 1 表のとおりであった。この結果からべと病の発 生に灌水が影響していると考えられた。 な打雨よけ栽 培では，ホウレンソウ葉に夜露を結ばないことを確認 している。

(2) 剂型別 TPN によるべと病防除効果について ホウレンソウのベと病防除薬剤はダュニール水和剤 14日前 2 回以内の登録のみであるが, 水を使用しない こととべと病の発病抑制が関連づけられるかをみるた めにダコニール粉剤の使用を試みた結果は第 2 表のと おりであったここの結果から水とべと病菌の活動は関 連があり, 水の状態はそれが防除薬液としても影響を 与えるものと思われる。

第 1 表 灌水とべと病発生

\begin{tabular}{|c|c|c|c|c|c|}
\hline 区 & $\begin{array}{l}\text { 調查 } \\
\text { 株数 }\end{array}$ & $\begin{array}{l}\text { 登病 } \\
\text { 株数 }\end{array}$ & 発病葉 & $\begin{array}{l}\text { 病斑面 } \\
\text { 積 } \%\end{array}$ & 備 考 \\
\hline トタン被覆 & 75 & 3 & 3 & 10 & 調査 \\
\hline 灌 & 75 & 36 & 40 & 18 & 10月 10 日 \\
\hline
\end{tabular}

第 2 表 剂型別 TPN と防除効果

\begin{tabular}{lccccl}
\hline \hline 剂 & 型 & 調查株数 & 発病株数 & 発病株率 & \multicolumn{1}{l}{ 備 } \\
\hline TPN 600 倍 & 75 & 30 & 40 & 調査 \\
TPN 800 倍 & 75 & 30 & 40 & 10月10日 \\
TPN 粉 & 剂 & 75 & 18 & 24 & \\
対 & 照 & 75 & 36 & 48 & \\
\hline
\end{tabular}

